\title{
Central Challenges Confronting the African State: Rethinking Its Role in Development
}

\author{
Toure Kazah-Toure*
}

\begin{abstract}
This paper focuses on the central challenges confronting the African state in the context of the neo-liberal offensive to render the continent more vulnerable. Historically the African state was a creation of the colonisers to serve their interests. In the post-colonial condition it has principally served the interests of tiny, powerful circles and their foreign backers, rather than those of the generality of the African people. Prolonged authoritarianism on the continent has been maintained principally through the state. Only through popular democratic transformation of the state will the continent march towards development. Historically development in all spheres has never been attained anywhere independent of the central role of the state.

In the post-Cold War period America is on course to drag African governments, political leaders and the continent's economic resources into another phase of imperialist domination. The terms, terrain, politics and direction of the so-called war on terror are determined without consultations with the African people. This paper focuses on central issues of regional and continental integration, conflicts, citizenship, control and mobilisation resources, true democracy, managing pluralism, constitutionalism, participation, accountability and security. These require urgent tackling to ensure more forged unity and protection of the continent. The analysis delves into concrete realities and makes suggestions for ending the quagmire of the African state.
\end{abstract}

\section{Résumé}

Cette étude porte sur les défis centraux que doit relever l'état Africain dans le contexte de l'offensive néolibérale visant à rendre le continent plus vulnérable. Historiquement, l'état Africain a été créé par les colonisateurs pour servir leurs intérêts. En

* Department of History, ABU, Zaria, Nigeria, Email: tktoure@yahoo.com 
situation postcoloniale, l'état a essentiellement servi les intérêts de cercles minuscules et puissants et de leurs partisans étrangers plutôt que ceux de l'ensemble du peuple Africain. L'autoritarisme prolongé sur le continent africain a été maintenu fondamentalement par le biais de l'état. Ce n'est que par une transformation populaire et démocratique de l'état que le continent marchera vers le développement. Historiquement, le développement dans toutes les sphères n'a jamais été réalisé indépendamment du rôle central de l'état.

Dans la période qui a suivi la Guerre Froide, l'Amérique est en course pour entraîner les gouvernements africains, les dirigeants politiques et les ressources économiques du continent vers une autre phase de domination économique. Les termes, le terrain, la politique et l'orientation de la prétendue guerre contre le terrorisme sont décidés sans consulter le peuple Africain. Cette étude se penche sur les questions centrales d'intégration régionale et continentale, de conflits, de citoyenneté, de contrôle et de mobilisation des ressources, de véritable démocratie, de gestion du pluralisme, de constitutionnalisme, de participation, de responsabilisation et de sécurité. Ces questions exigent de s'y attaquer afin d'assurer une unité et une protection du continent plus élaborées. L'analyse s'attarde sur des réalités concrètes et propose des suggestions visant à mettre fin à ce bourbier dans lequel est plongé l'état Africain.

\section{Introduction}

At various historical eras of Africa's unequal relationships with the West, the continent suffered from many injustices, including slavery and colonialism. The crudest product of colonisation was white settler dominated, the last product of which was apartheid in South Africa. The continent was a major experimental theatre and concrete terrain for battles in the course of the Cold War. America and other Western allies stood as promoters and backers of apartheid. Furthermore they spearheaded the fuelling of authoritarianism and bad governance in many African countries, whether these regimes were led by civilians or military dictators. It was common for the leaders of the hegemonic nations to demonise African patriots and nationalists who were committed to charting an alternative course for the development of their countries and peoples. One practical side of this campaign was the fact that imperialism sponsored terror, either directly or indirectly, against anticolonialist and anti-imperialist democratic movements and governments on the continent. As Mahmood Mamdani argues the continent was trapped in the web of the Cold War on terms set by foreign rival powers, and the people of Africa paid heavily for this (Mamdani 2004: 28).

Africa finds itself once more, in the contemporary phase of global hegemony, being led by an imperial superpower that lays claim to 
democracy domestically but practices military aggression and dictatorship externally. After the September 1 1, 2001 attacks on New York and Washington, America accelerated its unilateral drive for a Goliath-like domination that has been accompanied with armed-twisting of reluctant nations and threats and has involved dragging on board some African political leaders into what President George W. Bush calls the 'war on terror'. The terms of the war, its terrain, politics and direction, have been determined without consultations with the African people. Barely ten days after the September 11 attacks, Bush warned the rest of the world in unambiguous terms that all countries and segments of humanity are either with the USA or are with the terrorists (Wallensteen 2003: 229). The implications of this for Africa have to be dissected. Despite efforts made by some governments, regional and continental organisations and civil society movements, there are prevailing impediments towards defending Africa's interests and its true emancipation.

\section{The Cold War and Terror}

Very complex processes and promotion of proxy actors by modern hegemonies have contributed much to the germination, growth and expansion of state and non-state terror. In a fertile analysis of the present global context Eric Hobsbawm maintains that devastating armed operations are no longer monopolised by governments and their state agents. Another dimension is that the contending forces do not have commonality in terms of characteristics, status or objectives, but all have the willingness and determination to use violence (Hobsbawm 2002).

The issue of terror in Africa has witnessed this shift. In the history of the anti-colonial liberation struggles in Africa and the postindependence armed uprisings against dictatorial and despotic regimes, violence was directed at institutions and forces representing the state. Generally attacks were not directed at the civilian population. Many armed movements considered the latter as near sacred, and thus guerrilla fighters blended with the people and the civil society like fish in the water.

The most brutal shift was demonstrated in the wars in Sierra Leone and Liberia, where the civilian population had to run from both the forces of the state and the rebels. The people either sought protection 
in camps set up by international peacekeepers or in refugee camps across the national frontiers. Mostly both the state forces and rebels treated their fellow citizens as targets. Nowadays armed groups in Africa demonstrate loyalty only to the warlords and are committed to looting from the people. In the worst circumstances civilians are killed, while some have their limbs severed.

In the late Cold War years there was promotion of terror against some African governments that resisted the path the West wanted for all nation states. From the 1960s to the early 1990s the United States, leading the Western bloc, viewed and treated Africa as an ideological and political battleground within the Cold War contestation with the Soviet Union. The issue of democracy in Africa, in any variety, was not on the imperialists' agenda. Rather the US supported authoritarian regimes and opposed those that were nationalistic and socialist. Financial aid and loans were pumped to regimes that were proxies of imperialist interests, regardless of the repression of the citizenry by such authoritarian and undemocratic governments. Convert and overt operations were waged against African states that sought alternative development models at the political, economic, security and military levels. Thus America has a history of being at the head of external promoters of terrorist movements in Africa. This was the case in Angola, for example, where Washington backed UNITA to fight the MPLA regime.

In a parallel manner the United States sponsored the 'Contra' terrorists to carry out atrocities to show the people of Nicaragua that the radical development alternative embarked on by the Sandinista government has no future (Mamdani 2004:14). The Sandinistas were demonised by President Reagan as evil communists. Noam Chomsky stresses that when Nicaragua took the matter to the World Court in 1986, a judgement against the USA was passed for 'unlawful use of force', and part of the ruling demanded that America pay reparations to Nicaragua (Chomsky 1999). However, before the case was even heard, the USA had withdrawn from the court, and it subsequently refused to recognise the ruling. As Roger Burbach argues, this was a clear demonstration of American disregard and disrespect for international law (Burbach 2003). The US then proceeded to veto a UN Security Council resolution that called on all states, without mentioning any in particular, 'to adhere to international law' (Chomsky 2002).

During the Reagan administration America increasingly turned to the apartheid regime in South Africa, which unleashed proxy state ter- 
rorism in neighbouring countries. The South African military and its agents actively fought on Angolan territory alongside UNITA. It was involved in acts of destabilisation and devastation in other frontline states. A key objective of the massive destruction of infrastructure and other social and economic targets in the region was to create traumatising horrors both physically and psychologically in order to maintain the racist position that Africans, on their own, cannot rule themselves without so-called tribal conflicts (Mamdani 2004). As in the case of Nicaragua many of the Southern Africa government's enemies were portrayed as communists promoting unworkable and disastrous development alternatives.

The Resistencia National Mocambicana (Renamo) in Mozambique was created in the mid-1970s by the illegal white minority regime in Rhodesia in collaboration with former Portuguese colonialists. The Rhodesian settler regime launched an undeclared war to cripple the FRELIMO government because of Mozambican support for the Rhodesian national liberation movement. According to Johan Leidi, after the independence struggle triumphed in Rhodesia and the country was renamed Zimbabwe, apartheid South Africa inherited Renamo (Leidi 2003). Coupled with the Reagan administration's policy of 'constructive engagement' with South Africa, the terror arsenal of the Renamo terrorists was oiled through the apartheid military. Mamdani stresses that in the process the havoc caused was to prove to the population that the Frelimo-led nationalist government could not assure law and order (Mamdani 2003). This devastating war virtually destroyed all the development efforts of the Mozambican government and lasted for over 16 years, until the peace accord of 1992.

Imperialist-backed terrorist movements in Angola and Mozambique targeted communities and infrastructure, causing enormous ruinous effects. In the course of the period 1980-1988 America and Britain supported state terrorism by racist South Africa and its military offensives in the region. In the process the violent aggression caused over $\$ 60$ billion in damage and 1.5 million deaths. Inside South Africa there was large-scale state and related violence and repression that resulted in thousands of deaths (Chomsky 2003). Yet for the backers of apartheid, both local and international, it was the liberation movement that represented 'terrorism'. Never for once was apartheid South Africa classified by official America as a rogue state promoting state terrorism. Instead, as Chomsky points out, the apartheid regime was a valuable ally of the 
West, and it was praised for its supposed role in 'constructive engagements' (Chomsky 2003).

To defy the dictates of hegemonic power was the criterion that qualified a country for being classified as a rogue state. In 1986 the Reagan administration bombed Libya and justified the aggression on the basis of self-defence (Chomsky 1999). This was the first direct modern American state terrorism in Africa. At no time did America declare war on Libya, and in due course it officially classified Libya alongside Cuba, Iran, and North Korea as rogue states. At the time of the initial declaration official America was celebrating secularist Iraq, as it was yet to be labelled a rogue state. The US government supported Baghdad in the war with Islamist Iran and provided Iraq with deadly weapons, including chemical ones, that were used against both external enemies and internal opposition. Saddam Hussein, then a worthy client of the West, was even used 'to train several hundreds of Libyans sent to Iraq by the United States so that they could overthrow the Qaddafi government' (Chomsky 1999).

\section{Hegemonic Iniluences on Economic and Political Reforms}

Across Africa, mostly from the 1960s, many nationalist regimes were overthrown. The West was linked with many coups that installed tyrannical dictatorships. Then, as Issa Shivji succinctly puts it, authoritarianism was not considered bad by 'today's champions of democracy and good governance' (Shivji 2003). The hegemonic neo-liberal Western political leaders and the Bretton Woods Institutions (BWI) portray the African people as helpless victims of bad leadership. For them African people are not the agencies of change and African societies are merely at the mercy of bad governance. This somehow implies that only the hegemons and the donor community-in collaboration with those they consider 'good' African political leaders-can save the continent.

From the early 1980s many African governments-regardless of the nature of the state, economic policies and political orientation-have been gripped by economic crisis and have responded by accepting neoliberal structural adjustment programmes (SAPs) sponsored by the International Monetary Fund (IMF) and the World Bank. SAPs, in reality, promote a dominant role for market forces in the economy, deregulation, devaluation of national currencies, retrenchment of workers 
in the public and private sectors, privatisation of public property, withdrawal of subsidies and government retreat in the area of social provisioning and welfare services (Bangura 2001; Beckman 1992; Mkandawire and Olukoshi 1995).

The beneficiaries of privatisation and commercialisation of public companies have basically been limited to key actors of the ruling classes and foreign companies, as they go about accumulating wealth and plundering the public sphere without the consent of the people. The health, education, water, electricity and other sectors have seriously declined. Many local industries, no longer able to afford foreign exchange or to 'withstand the imports of cheap goods' (Shivji 2003), have gone bankrupt. The capacity of the state has been weakened, and in the worst cases the state has degenerated or even collapsed. An analysis by Yusuf Bangura (2001) vividly depicts the ways in which the state has distanced itself from the interests of the people by retreating from the provision of public services, infrastructure and security.

Global political trends have also weakened the African state. With the removal of the Berlin Wall in 1989, followed by the disintegration of the Soviet Union, there was no longer any serious threat to the interests of imperialists. African governments lost room to manoeuvre in their relations with the West, and imperialism began to design and promote a neo-liberal political agenda for the continent. As Anyang' Nyong'o points out, a key component of the new strategy was to argue that time had run out for 'authoritarian' regimes in Africa and to promote a political project of 'democratisation' that included multi-party political systems, protection of human rights and promotion of 'good governance' (Shivji 2005).

It was as if nothing had been accomplished in Africa before this, yet the reality is that, despite all sorts of problems, some gains were made in the 1960s and 1970s in quite a number of countries, including the establishment and maintainance of institutions that the citizenry cherished. This honeymoon ended when economic and political crises deepened in the era of structural reforms. By the mid-1980s many states had sunk into deeper crises through the implementation of neo-liberal reforms. Many workers, peasants, women groups, students, academics, farmers and professionals became increasingly restive throughout Africa.

Thus, due to both the global context of the end of the Cold war and the internal dynamics of politics in Africa, popular forces and opposi- 
tion parties could no longer be repressed. Adebayo Olukoshi argues that this new opening, however, had caveats for political forces that wanted to transcend what the global hegemons desired for the continent. First, the rise of global neo-liberalism not only meant that internal political reforms and changes were inaugurated in conditions of economic decline but also that elected governments had to reckon with 'the hegemonic political forces in the international system that had themselves taken on board the neo-liberal ideology of the market in dealing with the countries of the Third world in general and Africa in particular' (Olukoshi 1998). Second, the 'emergence in the post-Cold War international system of conditions favouring political reforms in Africa did not simultaneously produce conditions for the reversal, or even tempering, of neo-liberalism or structural adjustment' (Olukoshi 1998). Third, the post-cold war order did not 'produce a greater freedom of choice of economic policy direction for the countries of the Third World', especially in Africa (Olukoshi 1998).

\section{Airica in the Post-September 11 Global Hegemonic Ofiensive}

In 1998, Al-Qaeda bombs destroyed the America embassies in Nairobi and Dar es Salaam, killing hundreds of people, mostly innocent Africans. Three years later the offensive was carried to American territory when terrorists hijacked commercial airliners and crashed them into the World Trade Centre in New York and the Pentagon in Washington. About 4,000 people perished, mainly civilians, among whom were citizens of over 60 nations (Wallensteen 2003). Mamdani argues that these attacks, and the American response in the form of a 'war on terror', set in motion a new phase of state and non-state terror whereby 'victims are not necessarily the target; victims may as well be chosen by lottery' (Mamdani 2004).

The American unilateral course in international politics was soon spelt out. Addressing a joint session of the United States Congress on September 20, 2001, President Bush clearly defined how unlimited the scope of the frontiers and targets of the American war on terror were to be. He declared that "our war on terror begins with al-Qaeda but it does not end there. It will not end until every terrorist group of global reach has been found, stopped and defeated' (cited in Wallensteen 2003). In all the subsequent American political and military actions the UN has 
larely been disregarded, nor has the yardstick for qualifying groups as terrorist been defined.

Through this vagueness nationalist, patriotic movements and organisations can easily be labelled as terrorists and subjected to reprisals. It is also possible to use the pretence of terrorism to deal with states that either defer or resist unilateral US policies. Indeed Bush clearly implied that other nations should no longer exercise critical judgement or follow independent paths. They were warned to either accept the new American global commitment and involvement or be considered enemies: 'every nation in every region now has a decision to make: Either you are with us, or you are with the terrorists' (cited in Wallensteen 2003). Since then many African governments have joined the bandwagon by depicting as terrorists all kinds of political opponents and rival groups that are in competition for political power (Mamdani 2004), and some of the political leaders on the continent have become completely subservient to the US.

What Bush's September 20, 2001 declaration means to the rest of humanity is that American interests have primacy over any other considerations in the international system. In effect only weaker nations, those of Africa included, have to abide by multilateral laws and decisions. This is dangerous for humanity. As observed on the eve of the military attack on Afghanistan in 2001 by the Spanish judge, Baltesar Garzon, 'lasting peace and freedom can be achieved only with legality, justice, respect for diversity, defense of human rights and measured and fair responses' in the global system (cited in Burbach 2003).

In its current hegemonic drive the US has 'spread carnage and war, violating civil liberties and human rights' in different locations around the world (Burbach 2003). The democratic voices of American civil society do not matter, and the world is increasingly sharply divided, with the interests of majority of humanity totally ignored by the neoconservatives in control of the White House. As Burbach (2003) observes, on the 'one side stands an arrogant unilateralist clique in the US that engages in state terrorism and human rights abuses while tearing up international treaties', while on the other side 'is a global movement that is determined to advance a broad conception of human rights and human dignity through the utilisation of law, extradition treaties and limited policing activities.' What is happening is a fundamental struggle over where globalisation in the context of state and non-state terror will take humanity. The big question is whether the powerful economic 
and political interests of the hegemons, led by neo-conservative political leaders, "will create a new world order that relies on intervention and state terrorism, or whether a globalist perspective from below based on a more just and egalitarian conception of the world will gain ascendancy' (Burbach 2003).

\section{Oil and the Strategic Importance of Airica}

At present the Bush administration maps out the control of the Atlantic waters of the 'Gulf of Guinea as a zone of special strategic interest' (Vanguard 2002). This is due to America's rethinking of its over-reliance on Middle East oil in the post-September 11 context. In 2000 Bush, as a presidential candidate, declared that Africa 'doesn't fit into the national strategic interests as far as I can see' (Canadian Press 2002), but after coming to power, and faced with increased turbulence in the Middle East, especially after the invasion and occupation of Iraq, America has turned in the direction of Africa for strategic oil interests.

At one time African oil fields were thought to account for only about 6 percent of the world's known oil reserves, but in 2001 prospectors discovered a further 8 billion barrels of crude oil reserves, seven billion of them offshore from the Gulf of Guinea, far away from 'any social and political troubles' (Canadian Press 2002) and a conveniently short and safe journey from the United States, only half the distance from the Persian Gulf. Current projections are that cheap, high-quality oil from Africa will account for 25 percent of American oil consumption by 2020 . With world consumption expected to rise by almost 60 percent by 2020, African oil will reduce US dependence on Middle East oil dramatically (New York Times 2002). Meanwhile new oil fields ranging from Morocco and Western Sahara down the Atlantic coast to Angola are being discovered. The island country of Sao Tome and Principe, with a population of only 150,000, has given consent for a big US naval base on its small territory. Despite earlier denials by some officials the American congress and the pentagon have discussed the matter. There are other American military exchanges with other countries in West and Central Africa (Monbiot 2003).

Equatorial Guinea, hitherto perceived as an obscure enclave under bloodthirsty dictators, has become a country of interest because of oil. There are indications that suggest the existence of American military observer stations in Nigeria, Niger, Mali and Senegal, all located in the 
West African Sahel region, with obvious implications for future military policing by the superpower from the Sahelian region to the Atlantic Coast of West Africa.

The picture becomes clearer if one adds the ongoing American drive to play a role in the control of 1.25 billion barrels of known oil reserves in Sudan, which could even triple if the peace settlement between the Sudanese government and the Sudan People's Liberation Movement/ Army (SPLM/A) works out. The Chad-Cameroon oil pipeline is estimated to have cost $\$ 3.5$ billion and has been used for moving oil from Chad to the Atlantic coast since the end of 2004. Chad is expected to produce 255,000 barrels per day. Equatorial Guinea is expected to produce 350,000 barrels per day starting from 2005 (New York Times 2002), while the projection is that Nigeria will increase its production from 2 million barrels of oil per day to 3.5 million barrels by 2007. With America having lifted sanctions and re-established diplomatic relations with Libya this former 'rogue' state's oil reserves, the largest in Africa, are currently a focal point of interest to the West.

\section{Rethinking Airican Conflicts}

In 1994 about one million people were killed in state-perpetrated genocide targeted at Tutsis and moderate Hutus in Rwanda. This was the peak of the history of Hutu versus Tutsi atrocities, especially since the 1950s. Also it is estimated that over 4 million people have been killed in the violent conflicts in the Democratic Republic of the Congo (DRC) from 1994 onwards. Figures on internally displaced and homeless people were put at about 4 million in 2004. This excludes refugees that exited from elsewhere, most especially people from other war-ridden neighbouring states that moved into the DRC. However because oil is not involved, America does not show concern (Chomsky 2003: 105).

In many of the countries of the African Great Lakes region the state is not in control of many zones. Diverse armed groups, militias and warlords operate in various enclaves in the most violent ways. In connivance with some multinationals, militias such as the Mai Mai of the eastern DRC forcibly conscript people and use them as slaves in illegal gold, diamond and other mining activities as well as in drug and human trafficking. In addition the vicious chains of intra- and inter-state wars seem to be conspiring against the UN's peacekeeping efforts. In any case the history of UN peacekeeping and other interventions has been 
marked by dismal failure in both the DRC, right from the 1960s, and in Rwanda in 1994.

Linked to these conflicts is the problematic of managing the citizenship question in African countries, both within and across national boundaries (Adejumobi 2004: 4-8). The Great Lakes region has witnessed bloody internal and regional conflicts for decades, and it has been allowed to sink deeper into anarchy. In Côte d'Ivoire the question of citizenship, including belonging and exclusion, has given rise to violent xenophobia in which the state plays a central role in promoting the most divisive sectarianism that threatens security beyond national boundaries, with serious implication for the West Africa sub-region. If Africa is to leap forward, it must take the resolution of its numerous intra- and inter-state wars seriously.

\section{NEPAD as Airica's Development Model?}

Some African political leaders, for example, South Africa's Thabo Mbeki, seem to appreciate the historicity and political context of the present challenges confronting the continent. But it is baffling to find so many contradictions between ideals and practicability in what such leaders say. Mbeki enunciates the challenges facing African renewal and renaissance, which somehow influenced the formation of the African Union (AU) and its main development programme, the New Partnership for Africa's Development (NEPAD). The dominant position of the political leaders is that Africa has to reform its political and constitutional systems to enable the people to govern and to ensure that Africa becomes a continent where democracy and human rights reign 'to enable every African to play a role in deciding the future of our countries and continent' (Mbeki 2003). Mbeki stresses the need 'to respect and promote the dignity of all Africans' and calls for an end to violent interand intra-state conflicts on the continent. In addition, because of Africans' interdependence and common destiny, he recognises that authoritarianism in governance is unacceptable and should be given zero tolerance and that neutrality, as enshrined in the non-interference clause in the former OAU charter, is unacceptable in situations in which the state commits crimes against its people (Mbeki 2003: 3).

In promoting NEPAD, Mbeki argues that Africans must 'act to end poverty and underdevelopment', think for themselves (by not allowing external powers prescribe to them what should be done) and create 
their 'own development programmes and take responsibility for their success' (Mbeki 2003). The African state is seen to be at the centre of playing 'a developmental role, from the local to the national sphere of government' (Mbeki 2003). To achieve this, public servants have to internalise the idea that the people and their interests come first, which in turn means that political leaders must lead by example. Therefore a mechanism to fight corruption has to be entrenched that starts with the political leaders. Mbeki stresses that Africa has the human and material resources to confront the challenge of poverty and underdevelopment and build capacity for self-reliance. To him this does not mean repudiating mutually beneficial partnerships with developed countries, but Africa must not turn to slavish dependence on foreign aid (Mbeki 2003).

However, despite all these fine ideas, many analysts wonder whether NEPAD is an idea being pushed by the West. They point out that in many African countries the generality of the citizenry, trade unions, civil society, religious groups, opposition parties, academic and intellectual organisations and other democratic forces have not been engaged or formally consulted by the political leaders and technocrats that are constructing NEPAD (Akinrinade 2003; Bond 2003; Melber 2002). Moreover even some of the principal movers of the NEPAD project on the continent are no longer sounding optimistic. In 2004 President Abdoulaye Wade of Senegal, one of the leaders who spearheaded the creation of NEPAD, complained about the programme employing more staff from English-speaking countries than from Frenchspeaking ones. At a 2004 Durban conference attended by African leaders, the media widely reported Wade's criticism of NEPAD's approach to economic integration in which he concluded that NEPAD is essentially a waste of time and money. Analysts provide ample evidence that NEPAD is an old pro-imperialist project repackaged in new clothes by the neo-liberals (Bond 2003; Bujra 2004; Shivji 2004).

Thus it is time for committed national and pan-African movements, organisations and groupings to intensify efforts and co-ordinate actions on charting the course for the future of alternative economic development for the continent. Africans can no longer wait for the elite to take the lead. Labour movements, the youth, community leaders, civil society organisations, environmentalists, political parties, women's organisations and intellectuals need to articulate alternative views and present them to the African people. The culture of debate in both state and 
civic arenas has to be broadened. The political leaders and their consultants have not bothered to explain to citizens what happened to previous grandiose alternatives such as the Lagos Plan of Action.

\section{Reilecting on Socio-Economic and Political Challenges}

For Africa the debt crisis has been made worse by globalisation. In subSaharan Africa the overall total debt rose from $\$ 60$ billion to $\$ 206$ billion in the years 1980-2000 (Bond 2003). South Africa has the strongest economy in Africa and is rated in terms of purchasing power as the 21 st biggest economy in the world (Monbiot 2004), yet many see the country's Growth, Employment and Redistribution (GEAR) Strategyintroduced in 1996-as South Africa's self-imposed version of SAPs. A current problem is the South African government's attempt to run its social services, such as water and electricity, on free-market principles that the poor cannot afford. In 2000 pre-paid water metres were installed for the first time in Madlebe in KwaZulu Natal, and those who could not pay had their water supplies disconnected and had to resort to fetching water from streams and rivers. One result was one of the continent's worst-ever cholera outbreaks that infected over 100,000 people and killed 260' (Monbiot 2004). Although the Madlebe scheme was dropped, similar ones have continued elsewhere. In early October 2004 these were met with blockades, acts of sabotage and attacks on utility workers in some communities around Johannesburg.

For some years there has been a suspicion-even though the government denies it - that the IMF, Britain and the US have had advisers and consultants operating behind the scenes in South Africa from the time apartheid ended in order to promote the notion of 'market discipline' (Monbiot 2004). The proponents of market discipline argue that demanding 100 percent cost recovery is the only way to restrain wastage and will eventually help the poor to escape from poverty. A major consequence is that 'ten million people reported having had their water cut off.... and ten million experienced electricity disconnections' in a situation where general unemployment rose from 16 percent in 1995 to 30 percent in 2002 (with youth unemployment at 47 percent) (Bond 2003). Meanwhile a 2001 survey by The Economist showed that AIDS is cutting the rate of growth of the most economically active population. Between 1994 and 2000 nearly 500,000 jobs were lost (The Economist 2001b). 
On the other hand, compared with other countries on the continent, South Africa is a democracy with a viable electoral system. A war on corruption is ongoing in both the public and private sectors, and a vibrant civil society is playing a key role. There are viable opposition parties, political stability and a world-class legal system (The Economist $200 \mathrm{lb}$ ), along with a growing economy. As a result many Africans from other parts of the continent continue to flock into South Africa, which they see as 'the continent's great hope' (The Economist 2001a). Many African nationalists have maintained that there should be unlimited movement for people on the continent. This should certainly be the ultimate target, but there is need to recognise the fact that the present context is different from the decades prior to globalisation. In many regions of Africa the youth have not been given a role within the various sectors of the system. Millions of citizens are sceptical about their future within their national frontiers. Several countries on the continent are marked by failure of governments to provide opportunities for the citizenry, as the ruling circles behave like foreign occupiers.

In this age of globalisation there is so much information about places having opportunities for migrants-real, deceptive and illusionary. The youth question has to be taken seriously. Images of Africans escaping from the continent across the Sahara desert, the seas and oceans to the West and elsewhere in search of so-called greener postures, with many dying in the process, while others are treated in the most dehumanised ways, are beamed all over the world. The situation cannot be justified on the basis that Africans are flocking to the West because the Europeans came to Africa during colonialism without any visas. Something more concrete has to be done about the existing internal conditions in several African countries in terms of the social, economic, political and other rights of the people (Aina 1997).

Free and fair elections are still like a fairy tale in several African countries. The electoral processes are ineffective, while corruption, inflation, insecurity, disintegrating social services, retrenchment of workers and high unemployment bedevil public life. Africa's most populous country, Nigeria, provides an illustrative case study. In the vital education sector, for example, state neglect of the public universities is glaring. In the 2005 budget the federal government allocated a mere 8 percent of total expenditure to education. In 2003 the country made $\$ 26$ billion from the sale of oil in the international market, but the education sector was allocated a mere 3 percent in the national budget. 
Meanwhile intra-state conflicts are estimated to have killed hundreds of thousands of people, and after more than 45 years of independence Nigeria is yet to have a constitution derived from a national democratic debate (Chafe 2003).

Instead the political process of never-ending democratic experiments has been guided by military regimes with the collaboration of some conservative lawyers and politicians. As Aina puts it, without mentioning the country, in less than 50 years the people "have lived through colonisation, seen independence, experienced military coups, fought at least one civil war and have elected both a parliamentary style Prime Minister and an Executive President' (Aina 2003). Many years of the absence of gover-nance based on the consent of the citizenry and the resulting lack of an enduring democratic culture and practice have contributed to galvanizing various forces to pose challenges to the state and diverse factions of the ruling elite (Kazah-Toure 2004). As a result the emancipatory discourses on putting Nigeria back on a democratic course can no longer be restricted to a ruling elite that came to power through fraudulent elections, especially the most flawed, unfree and unfair elections of 2003 according to both local and international monitors (Bond 2003; Momoh 2005).

\section{Conclusion}

Africa requires a new internationalism led by anti-imperialist/antiglobalisation forces and pan-Africanist movements to challenge the present order. This has to be done if the African state is to be made more relevant in the development of the continent. In the history of the world no country has developed without the state playing a central role. As Patrick Bond maintains, a lot more needs to be done to shake off the 'debilitating economic and geopolitical aggression' in the present hegemonic and fundamentalists offensives (Bond 2003). The neo-liberal agenda on democracy, human rights, good governance, accountability and economic policies has not been determined or agreed on by the African people.

Africans require conscious efforts to keep the memories of the past alive and enable them to shape their destiny for a better future. What Edward Said (2003) calls on the people of the Middle East to do is worth rethinking for Africa. Let Africans expand the frontiers of their memories and rethink the historical and other processes that have led 
to their bondage, including the experiences of slavery, colonialism, racism, anti-colonial nationalism, post-colonial imperialism and proxy regimes that serve imperialist interests. In addition they have to reflect and rethink the scourges of coups and counter-coups, civil wars, interstate wars and sectarian conflicts confronting the continent. Africans also have to re-examine the leaders, ruling classes and governments that have been brutalising their own citizens and those at the centre of igniting hatred and xenophobia against sections of the citizenry. Fundamentally there ought to be a rethink about the promoters of the scourges and the beneficiaries at the different phases of the historical and political processes. It is worth noting that in each of the processes there have always been those who stood and struggled for the larger interests of the continent and the people on the one hand and, on the other hand, those who have never relented in keeping the continent within the hegemonic noose.

Africans have to do more to solidify regional and continental integration and employ more mechanisms towards the resolution of violent intra- and inter-state conflicts. The AU has to tackle the question of citizenship more vigorously. Citizens, civil society organisations and all stakeholders have to take up the challenges and work out positions to be pursued in concrete terms so that the control, development and distribution of resources are guided by the interest of Africa in all spheres. There is need for pan-African peoples' movements and political parties to intensify the struggles for democratic governance on the continent in opposition to the superimposed, neo-liberal, hegemonic variant. However, defiance can only be meaningful if real power in all spheres is taken seriously. If there is defiance without power, it will be as if nothing has been learned over the centuries.

If the continent is to free itself, determine its own place in the world and be a strong player in global politics, it must above all beat its tragic internal swords into ploughshares. The continent must put in place mechanisms to achieve true independence and advance its interests in the face of the current hegemonic hurricane. Only when Africa stops erecting its economic, political and social systems on weak and subservient foundations and instead builds its structures and institutions on solid ground will it achieve lofty heights for present and future generations. 


\section{References}

Adejumobi, S., 2004, 'Antinomy of Citizenship Negotiating Power or Social Existence?', Journal of West African Affairs, Vol.4, No.1.

Aina, T. A., 1997, Globalisation and Social Policy in Africa: Issues and Research Directions, Dakar: CODESRIA.

Aina, T. A., 2003, 'Scales of Suffering, Orders of Emancipation: Critical Issues in Democratic Development in Africa', African Sociological Review, Vol. 7, No. 1.

Akinrinade, S., 2003, 'The New Partnership for Africa's Development: Dispensing with the Begging Bowl or...', in E. Obadare and D. Oyewole, eds., The New Partnership for Africa's Development (NEPAD): Challenges and Developments, Lagos and London: CDD.

Anyang' Nyong'o, P., 2004, 'Elections and Democratic Transitions in Africa: The Kenyan Experience in the African Context', Nigerian Political Science Association Newsletter, Vol. 2, No. 3.

Bangura, Y., 2001, 'Globalisation and African Development', in R. Suttner, ed., Africa in the New Millennium, Uppsala: Nordiska Afrikainstitutet.

Beckman, B., 1992, 'Empowerment or Repression? The World Bank and the Politics of African Adjustment', in P. Gibbon, Y. Bangura and A. Ofstad, eds., Authoritarianism, Democracy, and Adjustment: The Politics of Economic Reform in Africa, Uppsala: Nordiska Africainstitutet.

Bond, P., 2003, 'Our Africa, Our World? Continental and International Policies and Politics', Plenary Address to Nordic Africa Days, Uppsala, Nordiska Africainstitutet, 4 October.

Bujra, A., 2004, 'Pan-African Political and Economic Visions of Development from the OAU to the AU: From the Lagos Plan of Action (LPA) to the New Partnership for African Development (NEPAD)', DPMF Occasional Paper, No.13, Addis Ababa: DPMF.

Burbach, Roger, 2003, 'Two 9/11s, One Story: To Understand Better What Happened in New York, Go Back to Chile in 1973', The Guardian, 11 September.

Chafe, K. S., 2004, 'In Defence of Sovereign National Conference in Nigeria', Kaduna Daily Trust, 30 July.

Chomsky, N., 1999, Acts of Aggression: Policing 'Rogue' States, New York: Seven Stories Press.

Chomsky, N., 2002, Reflections on 9-11, New York: Seven Stories Press.

Chomsky, N., 2003, Power and Terror: Post 9/1 1 Talks and Interviews, New York: Seven Stories Press.

Ginwala, F., 2003, 'The Role of Parliament in Meeting the Challenges of Globalisation to Democratic Governance in Africa', DPMF Occasional Paper No. 8, Addis Ababa: DPMF.

Hobsbawm, E., 2002, 'The Future of War and Peace', Counterpunch, 27 February.

Kazah-Toure, T., 2004, 'A Discourse on the Citizenship Question in Nigeria', Journal of West African Affairs, Vol.4, No.1.

Leidi, J., 2003, ‘Mozambique - a Bantu Nucleus or a Multicultural Society', paper presented at Nordic Africa Days, Uppsala, Nordiska Afrikainstitutet, 3-5 October. 
Mamdani, M., 2004, Good Muslim, Bad Muslim: America, the Cold war and the Origins of Terror, Zaria: Ahmadu Bello Press.

Mbeki, T., 2003, 'How Africans Can Deliver Africa', (http://www.vanguardnr.com/articles/2002/politics/pl08122003.html), 8 December.

Melber, H., 2002, 'The New Partnership for Africa's Development (NEPAD) Scope and Perspectives', in H. Melber, ed., The New Partnership for Africa's Development (NEPAD) - African Perspectives, Uppsala: Nordiska Afrikainstitutet.

Mkandawire, T., and Olukoshi, A. O., eds., 1995, Between Liberalisation and Oppression: The Politics of Structural Adjustment in Africa, Dakar: CODESRIA.

Momoh, A., 2005, 'Democracy or Good governance? Making Sense of Disempowerment in Nigeria', paper delivered at Jubril Bala Mohammed Fund Launch, 4 July.

Monbiot, G., 2003, 'A Wilful Blindness', The Guardian, 11 March.

Monbiot, G., 2004, 'Why Is Britain Using Aid Money to Persuade South Africa to Privatise the Public Services?', Guardian, 19 October.

New York Times, 2002, 'Africa Is Rising in Strategic Importance to Washington Policy Makers, 18 September.

Olukoshi, A. O., 1998, 'Economic Crisis, Multipartyism, and Opposition Politics in Contemporary Africa', in A.O. Olukoshi, ed., The Politics of Opposition in Contemporary Africa, Uppsala: Nordiska Afrikainstitutet.

Said, E., 2003, 'Worldly Humanism vs the Empire-builders', Counterpunch, 5 August .

Shivji, I. G., 2003, 'Good Governance, Bad Governance and the Quest for Democracy in Africa: An Alternative Perspective', Plenary Lecture at Nordic Africa Days, Uppsala, Nordiska Afrikainstitutet, 3-5 October.

Shivji, I. G., 2004, 'Pan-Africanism and Imperialism? Unity and Struggle Towards a New Africa', Billy Dudley Memorial Lecture Series No.2, Lagos: The Nigerian Political Science Association (NPSA).

The Canadian Press, 2002, 'America Has Its Sights on West Africa's Gulf of Guinea, 21 September.

The Economist, 2001a, Survey: South Africa, Africa's Great Black Hope, (http:/ www.economist.com/survey/displaystory.cfm? issue=20010224), 22 February

The Economist, 2001b, 'Survey: South Africa-Jobless and Joyless', (http:// www.economist.com/surveys/displayStory.cfm?issue=510685), 22 February.

Vanguard, 2002, 'US Moves to Secure African Oil Supplies', 30 September.

Wallensteen, P., 2003, Understanding Conflict Resolution: War, Peace and the Global System, London: SAGE Publications. 
